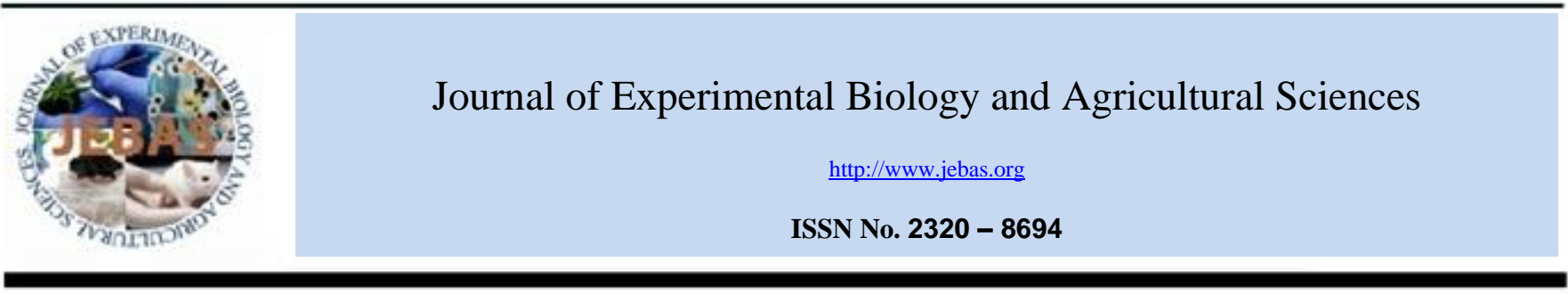

\title{
EFFECTS OF CRUDE EXTRACTS OF VARIOUS PIGMENTS ISOLATED FROM Spirulina platensis AND Chlorella vulgaris ON THE ANGIOGENESIS OF CHICK EMBRYO CHORIOALLANTOIC MEMBRANE (CAM)
}

\section{Haydee Evangeline H. Biscocho* and Johnny A. Ching}

Biological Sciences Department, College of Science and Computer StudiesDe La Salle University-Dasmariñas, City of Dasmariñas, Cavite, Philippines

Received - January 15, 2016; Revision - February 12, 2016; Accepted - March 23, 2016

Available Online - April 25, 2016

DOI: http://dx.doi.org/10.18006/2016.4(2).121.127

\section{KEYWORDS \\ Angiogenesis \\ S. platensis \\ C. vulgaris \\ Phycocyanin \\ Chlorophyll}

\begin{abstract}
This study was conducted to determine the angiogenic effects of different concentrations of phytopigments i.e. phycocyanin from Spirulina platensis and chlorophyll from Chlorella vulgaris on the chorioallantoic membrane (CAM) of developing chick embryo. Findings of study revealed that different concentrations of both crude phytopigments inhibit angiogenesis as shown by the continuous decrease of the vascular density index on the CAM of 10-day old chick embryo. However, Scheffe method showed that only $200 \mathrm{ppm}$ and $300 \mathrm{ppm}$ of crude phycocyanin and all experimental treatments of crude chlorophyll, including the $150 \mathrm{ppm}$, were able to significantly inhibit angiogenesis.It was also established that there is no significant difference in the angiogenic effects between the two phytopigments.
\end{abstract}

* Corresponding author

E-mail: hhbiscocho@dlsud.edu.ph (Haydee Evangeline H. Biscocho)

Peer review under responsibility of Journal of Experimental Biology and Agricultural Sciences.

Production and Hosting by Horizon Publisher India [HPI] (http://www.horizonpublisherindia.in/).

All rights reserved.
All the article published by Journal of Experimental Biology and Agricultural Sciences is licensed under a Creative Commons Attribution-NonCommercial 4.0 International License Based on a work at www.jebas.org.

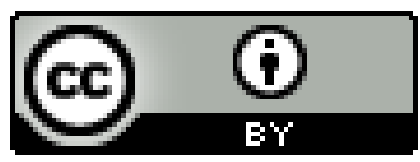




\section{Introduction}

Angiogenesis is a process of new blood vessels formation and it controlled by certain chemicals produced in the body. Chemicals such as aspartame and serotonin stimulate cells repair and are also responsible for repairing of damaged blood vessels or formation of new ones (Surve et al., 2015; Yesildal et al., 2015; Banskota et al., 2016). Further, some chemicals such as heparin and endostatin are responsible for stopping the process of cell repairing and are also responsible for the inhibition of the synthesis of stimulatory chemicals, these inhibitory chemicals are known as angiogenesis inhibitors (Zhao-Na et al., 2015; Jin-Yan et al., 2016). Uncontrolled angiogenesis is a major contributor in a number of diseases such as arthritis, diabetes-related blindness, psoriasis, tumor growth and metastasis (Heidenreich et al., 2009; Gayetsky et al., 2014). Anti-angiogenic compounds would be useful in treating diseases caused by uncontrolled angiogenesis. Proangiogenic compounds are also required in wound healing and may be useful in minimizing tissue damage following ischemia damage from heart attacks or stroke (Mousa \& Mohamed, 2004; Baharara et al., 2014).

Scientists and researchers are trying to use gene therapy to simulate this natural process by delivering different substances that may have potential positive or negative effects to angiogenesis of affected areas (Baharara et al., 2014). Various studies have been conducted to explore the possibilities of alternate anti-angiogenic substance based on herbal sources. Microalgae, such as Spirulina and Chlorella, received more attention from medical scientists as a nutraceutical and source of potential pharmaceuticals (Bishop \& Zubeck, 2012; AbdEl Baky \& El-Baroty, 2013). There are several studies which suggesting the ability of microalgae to inhibit viral replication, strengthen both the cellular and humoral arms of the immune system and cause regression and inhibition of cancers (Jensen et al., 2001; Tokusoglu \& üUnal, 2003). Spirulina is a planktonic blue-green alga found in warm water alkaline volcanic lakes. It has a dark blue-green color, because it is rich in a brilliant blue polypeptide called phycocyanin. Hayashi et al. (2006) reported that phycocyanin affects the stem cells found in bone marrow. Medical scientists reported that Spirulina not only stimulates the immune system but also enhances the body's ability to generate new blood cells (El-kott et al., 2007; Kedik et al., 2011). On the other hand, Chlorella is a single-celled green alga, which has highest known levels of chlorophyll of any plant. Hyo-Jin et al. (2006) reported that the extract of algae has stimulatory effect on the physical stamina and acts as liver detoxifier, bowel cleanser and as catalyst for the absorption of essential elements (Hyo-Jin et al., 2006). Chlorella is also considered as one of the most powerful nutraceuticals (Kyadari et al., 2013). Therefore, present study has been conducted to find out the angiogenic potentials of the extract of microalgae S.platensis and $C$. vulgaris on the chorioallantoic membrane (CAM) of developing chick embryo.

\section{Materials and methods}

\subsection{Collection and incubation of test embryos}

A total of one hundred fifty two-day old fertilized hen's eggs were obtained from a poultry farm. The eggs were transferred to the Biology Research Laboratory of De La Salle UniversityDasmariñas, Cavite and incubated at $37^{\circ} \mathrm{C}$ for another eight days.

2.2 Preparation of Algal extraction and determination of dry weight

Fresh S. platensis and C. vulgaris culture were obtained from the Aquaculture Department of the Southeast Asian Fisheries Development Centre (SEAFDEC) in Binangonan Freshwater Station located in the municipality of Binangonan, province of Rizal. The cultures were placed in an ice chest and transferred to the Biology Research Laboratory of De La Salle UniversityDasmariñas, Cavite for the extraction procedure. Each microalgal culture was centrifuged at $4000 \times g$ for $5 \mathrm{~min}$, pelletized, washed and resuspended twice with tap water. After washing, the supernatant was discarded and $40 \mathrm{~mL}$ of distilled water was added to the pelletized microalgae. The resuspended algal cells were then placed in a $50^{\circ} \mathrm{C}$ water bath for $24 \mathrm{~h}$ for autolysis. The autolysed cells were centrifuged at $10,000 \times g$ for $10 \mathrm{~min}$ and the supernatant was collected and dried in a rotary evaporator (Kightlinger et al., 2014). Two grams for each microalgae were used to determine their dry weight by using the formula (Boussiba \& Richmond, 1979): $\%$ dry weight $=[($ pan weight + dried powder $)-$ pan weight $] /$ pan weight (not dried)

\subsection{Phytopigment Assay}

\subsubsection{Phycocyanin assay}

Using $100 \mathrm{mM}$ phosphate buffer, $40 \mathrm{mg}$ of extracted Spirulina was used for quantitative analysis of crude phycocyanin through a spectrophotometer at $620 \mathrm{~nm}$ absorbency level using the formula (Boussiba \& Richmond, 1979):

$\%$ crude $\mathrm{CPC}=[\mathrm{A} 620 \times(10) \times(100)] / 3.39 \times(\mathrm{mg}$ sample $) \times$ (\% dry weight)

Where: 3.39 is extinction coefficient of CPC at $620 \mathrm{~nm}, 10$ is total volume and 100 represent $100 \%$.

\subsubsection{Chlorophyll assay}

Isolated chlorophyll level was quantified using $85 \%$ acetone and $50 \mathrm{mg}$ of Chlorella extracted by spectrophotometer at 666 $\mathrm{nm}$ and $642 \mathrm{~nm}$ against an $85 \%$ acetone/water blank absorbency level using the formula (Boussiba \& Richmond, 1979) 
$\%$ crude CCA $=[$ A666 $\times(10) \times(100)] / 9.93 \times(m g$ sample $) \times$ (\% dry weight)

Where: 9.93 is extinction coefficient of CCA at $666 \mathrm{~nm}, 10$ is total volume and 100 represent $100 \%$.

2.4 Preparation of different concentrations of crude phytopigments

Three different concentrations viz $150 \mathrm{ppm}, 200 \mathrm{ppm}$ and 300 ppm of S. platensis phycocyanin and $C$. vulgaris chlorophyll were prepared by double distilled sterile water. The desired concentrations were prepared from the crude extract obtained in the phytopigment assay using the dilution formula, $\mathrm{C}_{1} \mathrm{~V}_{1}=$ $\mathrm{C}_{2} \mathrm{~V}_{2}$, where $\mathrm{C}_{1} \mathrm{~V}_{1}$ are the initial concentration and volume of crude phytopigment and $\mathrm{C}_{2} \mathrm{~V}_{2}$ are the desired concentration and the final volume of crude phytopigment. The difference between the initial and final volume is the dilution factor used to obtain the desired concentrations.

2.5 Preparation of eggs for in situ sample application (West et al., 2000)

On the $4^{\text {th }}$ day of incubation, the eggs were removed from the incubator and were placed in a $37^{\circ} \mathrm{C}$ oven to prepare them in situ sample application. Each egg was swabbed with $70 \%$ alcohol and using a 2-ml syringe, a small hole at the pointed end of the shell was made to puncture the air sac. Using a drill bit, a $0.5-\mathrm{cm}$ square window in the shell was scored. The square shell was removed with a sharp pointed forceps to expose the CAM. The small square opening was covered by adhesive tape and each test egg was returned to the incubator horizontally, until treatment application on day 10 .

2.6 In situ sample application (West et al., 2000)

At the end of the 10-day incubation, 72 viable eggs were selected, 36 eggs for each phytopigment, to be the test embryos, 9 for each treatments. In a laminar flow cabinet, through the small square opening of each test egg, $0.3 \mathrm{ml}$ of the different concentrations of phytopigments and distilled water for the control group were administered. The opening was resealed and the eggs were returned to the incubator for further two days.

\subsection{Data Collection and Statistical Analysis}

Two days after the administration of crude phycocyanin and chlorophyll to the developing chick embryo, each of the test embryos was sacrificed and their CAM was prepared for observation of angiogenesis activity. The CAM was spread thinly in a petri dish and observed under stereomicroscope (Nikon ${ }^{\circledR}$ C-LED). Formed branch points or collaterals from four randomly selected areas of each CAM were counted and tabulated to determine the angiogenic effects of different concentrations of phycocyanin from $S$. platensis and chlorophyll from $C$. vulgaris.

To determine the significant difference in the angiogenic effects of different concentrations of crude phycocyanin from $S$. platensis and crude chlorophyll from $C$. vulgaris on the CAM of 10-day old chick embryos, one-way analysis of variance (ANOVA) was employed. Whenever there is significant difference, Scheffe method was used to compare individual treatment means.

\section{Results and Discussion}

Results of study revealed that the crude extract of phytopigments from $C$. vulgaris and $S$. platensis caused reduction in the formation and growth of blood vessels (Table $1)$.

Averages of 50.07 to 53.56 branch points were formed in the CAM of the tested embryos in the control treatment. Embryos treated with $150 \mathrm{ppm}$ of crude phycocyanin extracted of $S$. platensis formed an average of 51.19 branch points while those treated with $200 \mathrm{ppm}$ and $300 \mathrm{ppm}$ of the crude extract formed an average of 26.13 and 21.27 branch points respectively, a decrease of more than half compared to that of the control treatment. Similar results were observed for the embryos treated with crude chlorophyll extracted of C. vulgaris. An average of 45.04 branch points were formed from the CAM of test embryos treated with $150 \mathrm{ppm}$ of crude chlorophyll. While only an average of 25.54 and 20.54 branch points were formed for those treated with $200 \mathrm{ppm}$ and $300 \mathrm{ppm}$ of the crude extract, respectively.

Table 1 Average Number of Formed Branch Points Under the influence of various crude extracts .

\begin{tabular}{|l|c|c|}
\multirow{2}{*}{ Treatments } & \multicolumn{2}{c|}{ Average number of branch points } \\
\cline { 2 - 3 } Control & $53.56^{\mathrm{A}}$ & Applied with chlorophyll \\
\hline $150 \mathrm{ppm}$ & $51.19^{\mathrm{AX}}$ & $50.07^{\mathrm{A}}$ \\
\hline $200 \mathrm{ppm}$ & $26.13^{\mathrm{BX}}$ & $45.04^{\mathrm{BY}}$ \\
\hline \hline $300 \mathrm{ppm}$ & $21.27^{\mathrm{BX}}$ & $25.54^{\mathrm{CX}}$ \\
\hline
\end{tabular}

Letters A and B compared the different concentration of each phytopigment while letter X and Y compared the two phytopigments per treatment. Different letters indicate significant difference at 0.05 level 

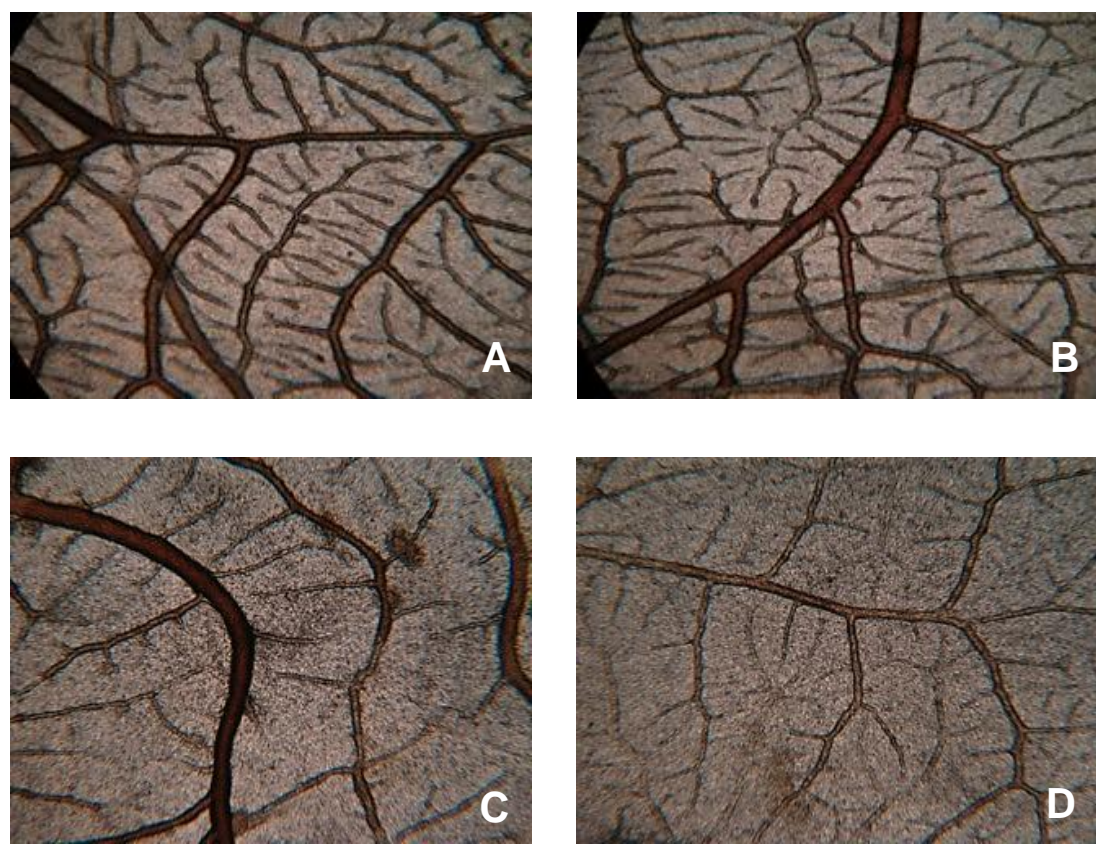

Treated with different concentrations of crude phycocyanin
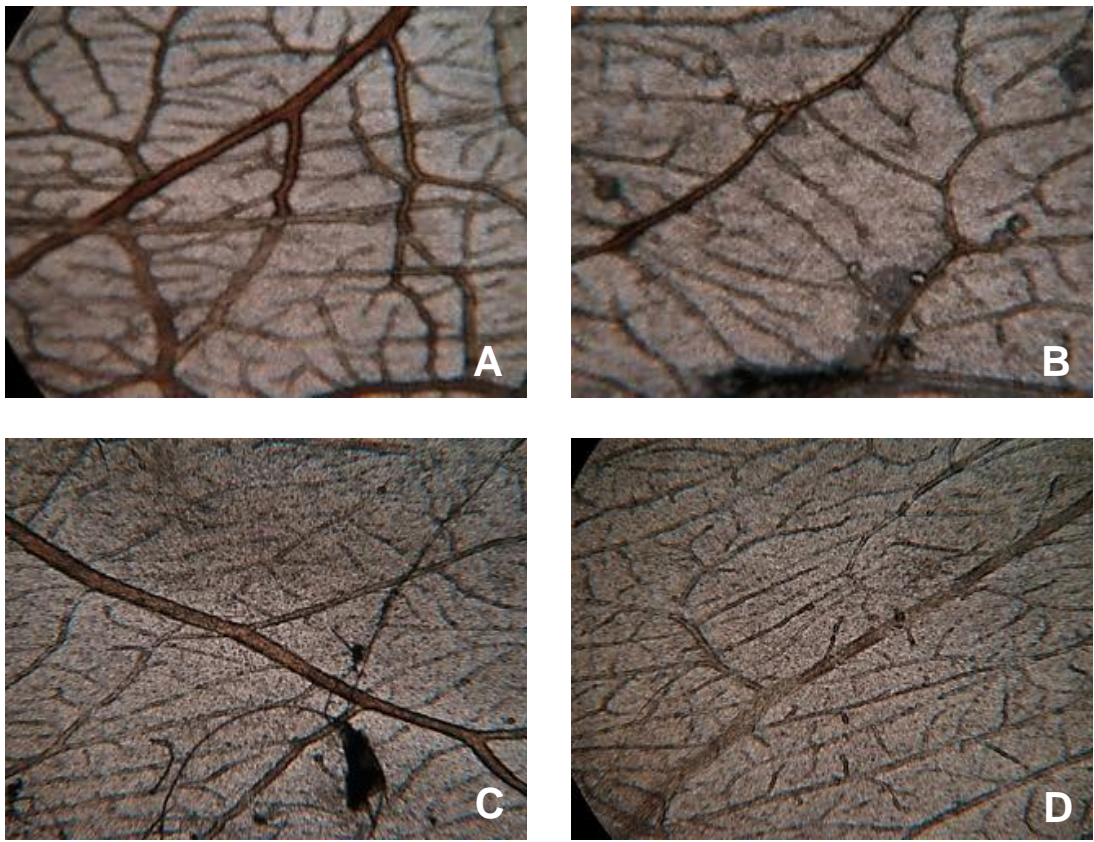

Treated with different concentrations of crude chlorophyll

Plate 1Photomicrographs (Nikon® C-LED 45x) of the CAM of representative embryos treated with different concentrations of crude phytopigments: (A) control, (B) $150 \mathrm{ppm}$, (C) $200 \mathrm{ppm}$, and (D) $300 \mathrm{pm}$.

Continuous reduction in the number of branch points formed was reported with increasing the concentration of the crude phytopigments, clearly indicated that both crude extracts had angiogenesis inhibition properties and signal the process to stop. Figure 1 shows the vascular density index of each treatment as they are compared with the control treatment.
Embryos treated with $150 \mathrm{ppm}$ of crude phycocyanin had a percent negative of 95.58 decreased in the angiogenesis or a mean difference of -2.37 as compared to the test embryos of the control. While percent negative of 48.79 and 39.71 were the decrease in the angiogenesis for the test embryos treated with $200 \mathrm{ppm}$ and $300 \mathrm{ppm}$ or a mean difference of -27.43 and -32.29 , respectively. 


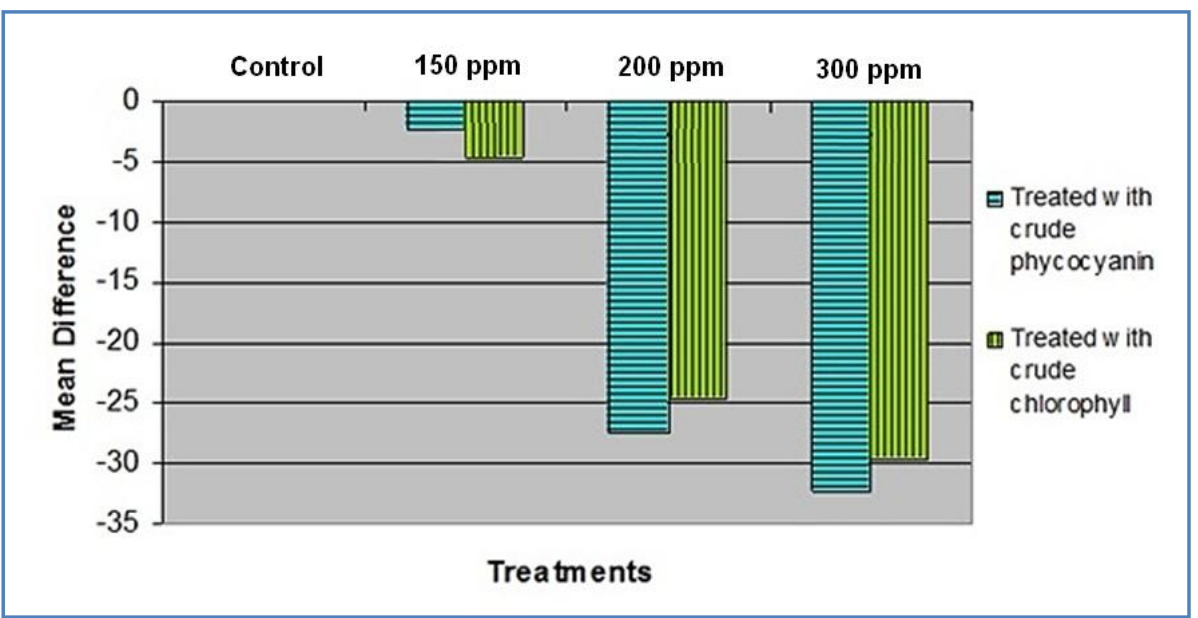

Figure 1 Vascular density index of test embryos treated with crude phytopigments as compared with the control.

Embryos treated with $150 \mathrm{ppm}$ of crude chlorophyll had a percent negative of 90.67 decreased in the angiogenesis or a mean difference of -4.67 as compared to the test embryos of the control. While percent negative of 51.01 and 41.02 were the decrease in the angiogenesis for the test embryos treated with $200 \mathrm{ppm}$ and $300 \mathrm{ppm}$ or a mean difference of -24.53 and -29.53 , respectively.

These results supported the claims that both phytopigments of Spirulina and Chlorella are effective in preventing diseases, such as cancer, brought about by uncontrolled angiogenesis (Tokusoglu \& üUnal, 2003; Hyo-Jin et al., 2006; Kedik et al., 2011). Previous researches revealed that high concentrations of phycocyanin and chlorophyll inhibited the in vitro growth of tumor cell lines, which indicating that some tumor cell lines are directly sensitive to phycocyanin or chlorophyll. Further, it was reported that these cell lines were inhibited by inhibiting angiogenesis (Jensen et al., 2001; Kyadari et al., 2013; Saini \& Sanyal, 2014). The number of branch points formed per treatment was also compared to determine the significant difference between crude extracts of phycocyanin and chlorophyll as angiogenesis inhibitors on the CAM of 1chick embryos. Figure 2 shows which of the two phytopigments inhibit angiogenesis more effectively.

All three concentrations of chlorophyll induced greater inhibition to the angiogenesis on the CAM of the test embryos compared to phycocyanin. Embryos treated with $150 \mathrm{ppm}$ crude phycocyanin formed an average of 51.19 compared to only 45.04 branch points formed in the test embryos treated with crude chlorophyll at the same concentration. Similar types of trend were observed with the other two concentrations viz 200ppm and 300ppm. Embryo treated with 200\& 300 ppm phycocyanin showed an average of $26.13 \& 21.27$ branch points whereas only $25.54 \& 20.54$ for crude chlorophyll. However, using one-way analysis of variance, there was no significant difference between the crude extract of 200 and 300 ppm of phycocyanin from $S$. platensis and the extract of chlorophyll from $C$. vulgaris in inhibiting angiogenesis to CAM of the test embryos. This only shows that both phytopigments were effective angiogenesis inhibitors.

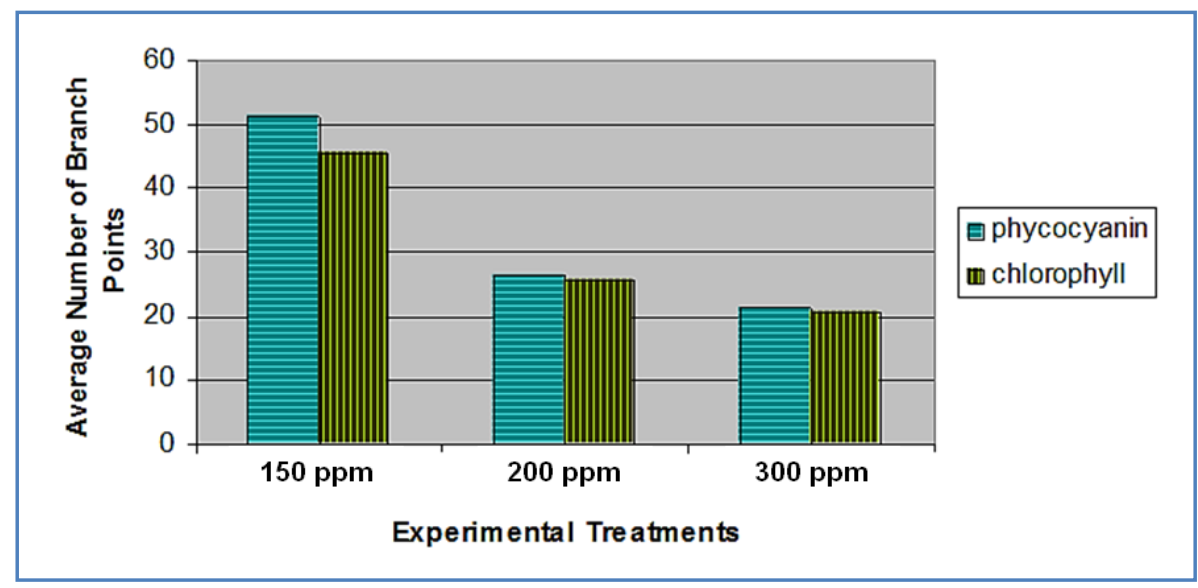

Figure 2 Average number of branch points formed in the CAM of test embryos from different experimental treatments. 


\begin{abstract}
126 Conclusions

Crude extract of phycocyanin and chlorophyll from S. platensis and C.vulgaris respectively, are angiogenesis inhibitors as shown by the continuous decrease of the vascular density index of the CAM of 10-day old chick embryo as their concentrations increased. Scheffe method reveals that $150 \mathrm{ppm}$ of crude phycocyanin did not significantly inhibit the angiogenesis on CAM of chick embryo while $200 \mathrm{ppm}$ and $300 \mathrm{ppm}$ inhibit angiogenesis. On the other hand, using the same statistical method, all experimental treatments of crude chlorophyll were able to significantly inhibit the angiogenesis on the CAM of chick embryos. There is no significant difference in the angiogenic effects between crude phycocyanin from $S$. platensis and crude chlorophyll from $C$. vulgaris on the CAM of 10-day chick embryo, meaning that both phytopigments induced the same effect as angiogenesis inhibitors.
\end{abstract}

\section{Conflict Of Interest}

The authors declare that there is no conflict of interests that could possibly arise.

\section{Acknowledgements}

The researchers express their deepest gratitude to Dr. Jimmy Masagca, Dr. Roger Guzman, Dr. Nieves Medina, and Dr. Cristina Salibayfor their unwavering support and intelligent critique.

\section{References}

Abd El-Baky HH, El-Baroty GS (2013) Healthy benefit of microalgal bioactive substances. Journal of Aquatic Science 1:1, 11-22. Retrieved from http://pubs.sciepub.com/jas/1/1/3/

Baharara J, Namvar F, Mousavi M, Ramezani T, Mohamad R (2014) Anti-angiogenesis effect of biogenic silver nanoparticles synthesized using Saliva officinalis on chick chorioallantoic membrane (CAM). Molecules 19: 1349813508. DOI: 10.3390/molecules 190913498

Banskota S, Gautam J, Regmi SC, Gurung P, Park M, Kim SJ, Nam T, Jeong B, Kim J (2016) BJ-1108, a 6-Amino-2,4,5Trimethylpyridin-3-ol Analog, Inhibits Serotonin-Induced Angiogenesis and Tumor Growth through PI3K/NOX Pathway. PLoS ONE 11:1, 1-16. DOI: 10.1371/journal.pone.0148133

Bishop WM, Zubeck HM (2012) Evaluation of microalgae for use as nutraceuticals and nutritional supplements. Journal of Nutrition \& Food Sciences 2:147. DOI: 10.4172/21559600.1000147

Boussiba S, Richmond A (1979) Isolation and purification of phycocyanins from blue-green alga Spirulina platensis.
Archives Microbiology 120: 155-159. Retrieved from http://link.springer.com/article/10.1007\%2FBF00409102

El-kott AF, Abd-El-Azim AO, Abdeen SH, Azab YA, Ismail MF (2007) Protective effect of Spirulina platensis on induced mammary tumour in rats: an immunohistochemical study. Egyptian Journal of Experimental Biology 3: 43-47. Retrieved from http://www.scopemed.org/?mno=188064

Gayetsky S, Museyko O, Engelke K, Käßer J, Hess A, Schett G (2014) Characterization and quantification of angiogenesis in rheumatoid arthritis in a mouse model using $\mu \mathrm{cT}$. BMC Musculoskeletal Disorders 15:1. DOI: 10.1186/1471-2474-15298

Hayashi O, Ono S, Ishii K, Shi Y, Hirahashi T, Katoh T (2006) Enhancement of proliferation and differentiation in bone marrow hematopoietic cells by Spirulina (Arthrospira) platensis in mice. Journal of Applied Phycology 18: 1, 47-56. Retrieved from http://eds.a.ebscohost. com/eds

Heidenreich R, Röcken M, Ghoreschi K (2009) Angiogenesis drives psoriasis pathogenesis. International Journal of Experimental Pathology 90: 3, 232-248. DOI: 10.1111/j.13652613.2009.00669.x

Hyo-Jin A, Hyun-Myung C, Hyeung-Suk P, Jae-Gab H, EunHee L, Young-Sig P, Jae-Young U, Seung-Heon H, HyungMin K (2006) Oral administration of hot water extracts of Chlorella vulgaris increases physical stamina in mice. Annals of Nutrition and Metabolism 50: 4, 380-386. Retrieved from http://eds.a.ebscohost. com/eds

Jensen G, Ginsberg D, Drapeau C (2001) Blue-green Algae as an Immuno-Enhancer and Biomodulator. Journal of American Nutraceutical Association 3: 24-30.Retrieved from http://www.ancientsuninc.com/BioModulatorImmunoEnhancer .pdf

Jin-Yan L, Tai-Yuan H, Ruo-Yu W, Jin-Ming Z, Gang W (2016) Deciphering the anti-angiogenic effect of endostatin/cyclophosphamide to normalize tumor microangium through notch signaling pathway in colon cancer. World Journal of Surgical Oncology 14:1, 1-8. DOI: 10.1186/s12957015-0761-9

Kedik SA, Yartsev EI, Sakaeva IV, Panov AV, Zhavoronok ES (2011) Influence of Spirulina and its component on the immune system. Russian Journal of Biopharmaceuticals 3: 3, 3-10. Retrieved from http://eds.a.ebscohost.com/eds

Kightlinger W, Chen K, Poumir A, Crunkleton DW, Price GL, Johannes TW (2014) Production and characterization of algae extract from Chlamydomonasreinhardtii. Electronic Journal of Biotechnology 17: 1, 14-18. DOI: 10.1016/j.ejbt.2013.12.003

Kyadari M, Fatma T, Azad R, Velpandian T (2013) Evaluation of antiangiogenic and antiproliferative potential of the organic extract of green algae Chlorella pyrenoidosa. Indian Journal of 
Pharmacology 45: 569-574. Retrieved from http://eds.b.ebscohost.com/eds

Mousa SA, Mohamed S (2004) Anti-angiogenic mechanisms and efficacy of the low molecular weight heparin, tinzaparin: anti-cancer efficacy. Oncology Report 12:683-688. Retrieved from https://www.hoffmancentre.com/assets/files/pdf/ articles

Saini MK, Sanyal SN (2014) Targeting angiogenic pathway for chemoprevention of experimental colon cancer using Cphycocyanin as cyclooxygenase-2 inhibitor. Biochemistry \& Cell Biology 92: 206-218. DOI: 10.1139/bcb-2014-0016

Surve ZR, Patil SR, Jha SM, Shetty GD, Manekar AP (2015) Angiogenic and antiangiogenic influence of streptozotocin and insulin on chorioallantoic membrane of chick embryo. Journal of Cell and Tissue Research 15: 4775-4782. Retrieved from http://eds.b.ebscohost.com/

Tokusoglu O, üUnal MK (2003) Biomass nutrient profiles of three microalgae: Spirulina platensis, Chlorella vulgaris, and
Isochrisisgalbana. Journal of Food Science 68: 224-226. Retrieved from http://eds.b.ebscohost.com/

West D, Thompson WD, Selis P, Burbridge M (2000) Angiogenesis Assays Using Chick Chorioallantoic Membrane. Methods in Molecular Medicine Vol. 46: Angiogenesis Protocols. Humana Press, Inc. Totowa, NJ. Retrieved from http://link.springer.com/protocol/10.1385\%2F1-59259-143$4 \% 3 \mathrm{~A} 107$

Yesildal F, Aydin FN, Deveci S, Tekin S, Aydin I, Mammadov R, Fermanli O, Avcu F, Acikel CH, Ozgurtas T (2015) Aspartame induces angiogenesis in vitro and in vivo models. Human \& Experimental Toxicology 34: 3, 260-265. DOI: $10.1177 / 0960327114537535$.

Zhao-Na L, Zhong-Fang Y, Guo-Ying M, Ming H, Li-Jun C, Ya-Li Z, Ming-Xu GE (2015) Augmented anti-angiogenesis activity of polysulfated heparin-endostatin and polyethylene glycol-endostatin in alkali burn-induced corneal ulcers in rabbits. Experimental \& Therapeutic Medicine 10: 3, 889-894. DOI: $10.3892 /$ etm.2015.2602. 